\title{
ADMINISTRASI KURIKULUM SEBAGAI PERANGKAT DALAM PENDIDIKAN
}

\author{
Nur Azizah \\ Email : 2010128220004@mhs.ulm.ac.id \\ Program Studi Pendidikan IPS Fakultas Keguruan dan Ilmu Pendidikan \\ Universitas Lambung Mangkurat \\ Banjarmasin
}

\begin{abstract}
Abstrak
Manajemen atau proses manajemen kurikulum meliputi perencanaan, pengembangan, implementasi, evaluasi, dan perbaikan kurikulum. Kurikulum pengembangan membutuhkan landasan yang kokoh dan didasarkan pada pemikiran dan penelitian yang matang. Penilaian atau penilaian kurikulum juga membantu menentukan tingkat pencapaian kurikulum. Berdasarkan hal tersebut dapat kita lihat bahwa peranan kurikulum dalam pendidikan formal sekolah sangatlah penting dan berpengaruh besar terhadap jenjang pendidikan. hasil. Guru berperan sebagai pelaksana teknis, pelaksana, adaptor, pengembang, dan peneliti. Tujuan artikel manajemen kurikulum ini adalah untuk menjelaskan peran penting manajemen kurikulum, proses atau tahapan manajemen kurikulum, dan peran aktif guru dalam manajemen kurikulum. Metode penelitian merupakan metode pilihan ketika mengumpulkan sumber dan sumber informasi lainnya, seperti mekanisme proses, peran guru dalam pengelolaan kurikulum, dan pentingnya kurikulum bagi keberhasilan pendidikan.
\end{abstract}

Kata kunci : Administrasi kurikulum, pendidikan, dan guru

\section{PENDAHULUAN}

Administrasi Secara sederhana administrasi berasal dari kata latin "ad" dan "ministro". Ad mempunyai arti "kepada" dan ministro berarti "melayani”. Secara bebas dapat diartikan bahwa administrasi itu merupakan pelayanan atau pengabdian terhadap subjek tertentu. Sedangkan dalam bahasa Inggris. Kata "ad" mempunyai arti yang sama dengan kata "to", yang berarti "ke" atau "kepada". Dan ministrare sama artinya dengan kata to serve atau to conduct yang berarti "melayani", "membantu", atau "mengarahkan". Dalam bahasa Inggris to administer berarti pula "mengatur", "memelihara" (to look after), dan "mengarahkan". Administrasi juga dapat diartikan sebagai kerja sama antar anggota organisasi untuk mencapai tujuan yang telah 
ditetapkan, berkaitan dengan kegiatan-kegiatan rutin, seperti administrasi pengajaran, keuangan, sarana prasarana dan lain-lain. Kurikulum secara etimologi berasal dari bahasa latin Curriculum, semula berarti a running course, specially a chariot race course, dan terdapat pula dalam bahasa perancis "Courier" artinya "to run" (berlari). Sedangkan secara terminologi berarti rancangan program pendidikan yang berisi serangkaian pengalaman yang diberikan kepada peserta didik untuk mencpai suatu tujuan yang ingin dicapai melalui serangkaian pengalaman belajar. Kurikulum dalam arti sempit diartikan sebagai kumpulan berbagai mata pelajaran yang diberikan kepada peserta didik melalui kegiatan yang dinamakan proses pembelajaran. Sedangkan pengertian lainya diartika sebagai deretan mata pelajaran yang diberikan oleh suatu lembaga pendidikan. Kurikulum secara lebih luas dapat diartikan sebagai keseluruhan proses pembelajaran yang direncanakan dan dibimbing di sekolah. Jadi, kurikulum merupakan seperangkat rencana dan pengaturan pendidikan atau pengajaran atau pengajaran dan hasil pendidikan atau pengajaran yang harus dicapai oleh anak didik, kegiatan belajar mengajar, pemberdayaan sumber daya pendidikan dalam pengembangan kurikulum itu sendiri. Bidang dari administrasi kurikulum adalah yang mencakup didalamnya pelaksanaan kurikulum, pebinaan, penyusunan silabus, persiapan harian, termasuk juga pembelajaran.

Kurikulum merupakan salah satu aspek yang memiliki pengaruh besar dalam mencapai keberhasilan sebuah pendidikan. Kurikulum adalah rancangan dan peraturan mengenai isi dan bahan pelajaran serta cara yang digunakan sebagai pedoman dalam pelaksanaan proses belajar mengajar. Dari hal ini bisa kita ketahui bahwa, dalam dunia pendidikan kurikulum digunakan sebagai penuntun arah dalam melaksanakan proses pendidikan. zaman. Seiring dengan perkembangan zaman maka dunia pendidikan baik itu formal maupun non formal maka harus menyesuaikan kurikulum pembelajarannya, jadi kurikulum pendidikan itu mengalami perkembangan yang yang cukup signifikan. Tentunya pengembangan kurikulum itu berorientasi kepada kebutuhan peserta didik yang berorientasi pada tujuan negara yaitu mensukseskan program pembangunan nasional, dengan mencetak sumber daya manusia berkualitas sesuai kebutuhan dalam pembangunan dan dapat menghasilkan peserta didik yang kualitas.

\section{PEMBAHASAN}

Kurikulum dapat diartikan secara sempit dan secara luas. Secara sempit kurikulum diartikan sejumlah mata pelajaran yang harus diikuti atau diambil siswa untuk dapat menamatkan 
pendidikannya, pada lembaga tertentu, sedangkan secara luas kurikulum diartikan dengan semua pengalaman belajar yang diberikan sekolah kepada siswa selama mengikuti pendidikan pada jenjang pendidikan tertentu. Usaha-usaha untuk memberikan pengalaman belajar kepada siswa dapat berlangsung di dalam kelas maupun di luar kelas baik yang dirancang secara tertulis maupun tidak, asal ditujukan untuk membentuk lulusan yang berkualitas. Dalam Undang-undang Nomor 20 tahun 2003 dikemukakan bahwa kurikulum adalah seperangkat rencana dan peraturan mengenai isi dan bahan pelajaran serta cara yang digunakan sebagai pedoman dalam pelaksanaan proses belajar mengajar. (Afriansyah, 2019). Kurikulum merupakan bagian terpenting dari sistem pendidikan Nasional, yang keberadaannya telah ada sejak awal keberadaan pendidikan Nasional. Kurikulum pada masa itu hanya memfokuskan ada membaca, menulis dan berhitung. Seiring dengan perkembangan zaman maka dunia pendidikan baik itu formal maupun non formal maka harus menyesuaikan kurikulum pembelajarannya sesuai jaman, jadi kurikulum pendidikan nasional itu mengalami perkembangan yang yang cukup signifikan. Tentunya pengembangan kurikulum itu berorientasi kepada kebutuhan peserta didik yang berorientasi pada kualitas atau mutu dengan tujuan negara dapat mensukseskan program pembangunan nasional, dengan mencetak sumber daya manusia berkualitas sesuai kebutuhan dalam pembangunan dan dapat menghasilkan peserta didik yang kualitas dan dapat bersaing secara kompetitif di pasar global.(Ali, 2013).

Proses perbaikan kurikulum di Indonesia terjadi sudah sangat banyak, yang mana dapat membawa dampak kepada mutu pendidikan di Indonesia, perbaikan kurikulum ini sendiri dilaksanakan agar terciptanya suatu pengeluaran atau hasil yang sangat efektif, dari adanya kurikulum pada masa belanda, jepang, dan dari kurikulum tahun 1964, sampai dengan pelaksanaan kurikulum sekarang 2013. Kurikulum merupakan suatu sistem yang memiliki komponen- komponen tertentu. Komponen itu adalah sebagai berikut:

1. Komponen tujuan Tujuan kurikulum merupakan sasaran yang hendak dicapai oleh suatu kurikulum. Tujuan kurikulum menurut taksonomi Bloom terbagi menjadi tiga, yaitu domain kognitif, domain afektif dan domain psikomotorik.

2. Komponen isi/materi pembelajaran Isi kurikulum merupakan kumpulan dari mata pelajaran yang menjadi bahan diskursus dalam proses belajar mengajar. Isi atau materi melibatkan banyak hal, bukan saja pengetahuan, tetapi juga keterampilan, konsep, sikap, dan nilai. Kompetensi merupakan keseluruhan sikap dan keterampilan yang ditunjukkan oleh peserta didik. 
3. Komponen metode Metode merupakan cara, jalan yang digunakan dalam proses pembelajaran. Metode dipilih berdasarkan tujuan yang dirumuskan. Seperti metode ceramah, diskusi dan lain-lain. Metode ini berkaitan dengan strategi yang harus dilakukan dalam rangka mencapai tujuan.

4. Komponen evaluasi Evaluasi atau penilain harus dilakukan secara bertahap, berkesinambungan, dan bersifat terbuka.18 Dari evaluasi ini diperoleh keterangan mengenai kegiatan dan kemajuan belajar siswa.

Adapun peranan kurikulum dalam pendidikan yang mana, peranan kurikulum dalam pendidikan formal di sekolah sangatlah strategis dan menentukan bagi tercapainya tujuan pendidikan. Kurikulum juga memiliki kedudukan dan posisi yang sangat sentral dalam keseluruhan proses pendidikan, bahkan kurikulum merupakan syarat mutlak dan bagian yang tak terpisahkan dari pendidikan itu sendiri. Sangat sulit dibayangkan bagaimana bentuk pelaksanaan suatu pendidikan di suatu lembaga pendidikan yang tidak memiliki kurikulum. (Asep Hernawan Herry \& Andriyani, 2014).

Proses administrasi kurikulum ada perencanaan, pelaksanaan, dan evalusi hasil. Dalam pengelolaan kurikulum adalah meliputi bidang perencanaan dan pengembangan, pelaksanaan, evaluasi dan perbaikan kurikulum. Perencanaan dan pengembangan kurikulum didasarkan pada asumsi bahwa telah tersedia informasi dan data tentang masalah-masalah dan kebutuhan yang mendasari disusunnya perencanaan yang tepat. Dan pelaksanaan kurikulum didasarkan pada asumsi bahwa kurikulum telah direncanakan dengan baik dan telah siap untuk diimplementasikan. Dengan demikian, perencanaan dan pengembangan kurikulum, pelaksanaan, evaluasi dan perbaikan kurikulum bergerak dalam satu sistem dalam siklus yang berkesinambungan yang secara bertahap, bergilir, berkesinambungan dalam lingkaran proses sistem pendidikan yang menyeluruh.(Nasir \& Samarinda, 2016).

Dari segi administrasi, kurikulum adalah kebijakan pemerintah di bidang pendidikan, yaitu cita-cita, harapan dan tuntutan masyarakat terhadap pendidikan itu sendiri. Pada dasarnya ditetapkan dalam kebijakan pendidikan pemerintah. Oleh karena itu, kebijakan tersebut dituangkan dalam landasan dan program kurikuler yang dapat diterapkan di lembaga pendidikan. Kurikulum bukan hanya sekedar dokumen mata pelajaran, melainkan memuat amanat/misi kehendak rakyat dalam pendidikan. Jika dilihat, konsep penting resume adalah tujuan materi pembelajaran, pengalaman dan keterampilan. Jadi dapat kita ketahui bahwa kurikulum adalah suatu perangkat dalam pembelajaran yang sangatpenting guna dapat 
mencapai apa yang diharapkan, yang mana kurikulum adalah seperangkat gagasan-gagasan baru, yang dirancang secara bersama dengan memikirkan kekurangan serta kelebihannya secara matang sehingga dapat menjadi suatu konsep yang tepat yang dpat digunakan padaproses pendidikan di Indonesia. Dan juga kurikulum 2013 ini menuntut siswa agar dapat mengembangkan keahlian, gagasan, kemampuan dan potensi yang dimiliki, sehingga disini lebih menciptakan siswa yang aktif dan mandiri, contohnya pada pelajaran tematik di SD pada bidang studi SBdP disini banyak sekali kegiatan-kegiatan pembelajaran yang lebih mengarahkan siswanya untuk mencoba sendiri melakukan eksperimeneksperiman dalm pembuatan suatukarya seni atau kerajinan, lebih memebebaskan siswa untuk berkreasi sesuai dengn kreatifitas masing-masing siswa. Sehingga siswapun tidak mengalamai rasa bosan dan jenuh dalam proses pembelajaran dan pembelajaran menjadi lebih menyenangkan.

Kurikulum memiliki fungsi yang sangat penting dalam pembentukan keterampilan manusia. Menurut Alexander, dikutip Wiryokusumo, fungsi kurikulum adalah adaptasi, integrasi, berbagai persiapan, pilihan dan diagnostik. Menurut Nurgiantoro (1988:4546), kurikulum memiliki tiga fungsi. Pertama, fungsi kurikulum sekolah adalah menyediakan alat untuk mencapai tujuan pendidikan yang diinginkan. Kurikulum juga dapat digunakan sebagai pedoman untuk mengatur kegiatan pendidikan berbasis sekolah seperti bidang studi, waktu, isi dan strategi. mempelajari. Kedua, kurikulum dapat mengontrol dan menjaga keseimbangan proses pendidikan. Dengan mengetahui kurikulum jenjang sekolah tertentu, maka kurikulum jenjang yang lebih tinggi dapat disesuaikan sehingga tidak terjadi pengulangan kegiatan pendidikan sebelumnya. Fungsi lain dari kurikulum adalah persiapan guru melalui pengetahuan tentang kurikulum tingkat yang lebih rendah. Ketiga, kurikulum perlu mempersiapkan kebutuhan masyarakat atau lapangan kerja agar kurikulum mencerminkan kebutuhan masyarakat. Artinya, mereka yang lulus sekolah setidaknya dapat memenuhi kebutuhan pekerjaan yang dibayar (profesional) di satu sisi dan siap untuk melanjutkan ke jenjang sekolah berikutnya (akademik) di sisi lain.

\section{PENUTUP}

\section{SIMPULAN}

Kurikulum merupakan seperangkat perencanaan dan peraturan mengenai isi dan bahan pelajaran serta cara yang digunakan sebagai pedoman dalam pelaksanaan proses belajar mengajar. Dengan kata lain, kurikulum adalah pedoman dalam menjalankan proses pendidikan. Kurikulum memiliki kedudukan dan posisi yang sangat sentral dalam keseluruhan proses 
hingga tercapainya tujuan pendidikan. Dalam pelaksanaannya kurikulum juga memerlukan pengawasan dan penilaian (evaluasi), sehingga halhal yang sudah tidak sesuai bisa dilakukan revisi atau perbaikan. Inilah yang dimaksud dengan kurikulum berkembang seiring zaman. Hal ini menunjukkan bahwa keberadaan kurikulum sangat penting dalam pelatihan. Selain itu, guru memiliki tugas sebagai praktisi teknis dalam mengimplementasikan kurikulum, sehingga mereka juga memainkan peran dalam manajemen kurikulum. Kurikulum ketat didefinisikan sebagai kumpulan mata pelajaran yang berbeda yang diajarkan kepada siswa melalui suatu kegiatan yang disebut proses belajar. Makna lain diartikan sebagai rangkaian mata pelajaran yang diberikan oleh suatu lembaga8. Kurikulum secara luas dapat diartikan sebagai keseluruhan proses pembelajaran yang direncanakan dan diarahkan oleh sekolah. 


\section{DAFTAR PUSTAKA}

Abbas, E. W. (2013b). Mewacanakan Pendidikan IPS (Cetakan Kedua). WAHANA Jaya Abadi. http://eprints.ulm.ac.id/5481/

Abbas, E. W. Dosen Pengampu: Prof. Dr. Ersis Warmansyah Abbas, M. Pd Jumriani, M. Pd.

Afriansyah, H. (2019). 2. ADMINISTRASI KURIKULUM.

Aklades, A. (2019). Administrasi Kurikulum.

Andriani, W. (2020). Pentingnya Perkembangan Pembaharuan Kurikulum dan Permasalahannya.

Fauziah, MW (2019). Administrasi Kurikulum.

Nasir, M., \& Samarinda, I. (2016). MANAJEMEN KURIKULUM DALAM PENDIDIKAN. Manajemen Kurikulum Dalam Pendidikan Syamil.

Riska, S. A., \& Afriansyah, H. (2019). Administrasi Kurikulum.

Rohmaniah, A. (2016). Analisis Implementasi Administrasi Kurikulum Pembelajaran Pelajaran Agama Terhadap Prestasi Pembelajaran Agama Kelas VII di Madrasah Tsanawiyah Takhassus AlQur'an Serangan Bonang Demak Tahun Pelajaran 2015/2016 (Doctoral dissertation, STAIN Kudus).

Sufairoh. (2010). Pendekatan Saintifik \& Model Pembelajaran K-13. Jurnal Pendidikan Profesional. 